\title{
Characterization of Leachate from a Woodwaste Pile
}

\author{
Wendong Tao, ${ }^{1 *}$ Ken J. Hall, ${ }^{1}$ Arash Masbough, ${ }^{1}$ Kevin Frankowski ${ }^{1}$ \\ and Sheldon J.B. Duff ${ }^{2}$ \\ ${ }^{1}$ Department of Civil Engineering, University of British Columbia, 6250 Applied Science Lane, \\ Vancouver, British Columbia V6T 1 Z4 \\ ${ }^{2}$ Department of Chemical and Biological Engineering, University of British Columbia, 2216 Main Mall, \\ Vancouver, British Columbia V6T $1 Z 4$
}

\begin{abstract}
Leachate was generated when precipitation percolated through a pile of woodwaste, including trimmings, off-specification wood chips, shredded bark and roots, and sawdust from several cedar processing mills. The "young" woodwaste leachate produced in the pile's placement period was amber, acidic ( $\mathrm{pH}$ 3.4-3.7), nutrient-poor (inorganic nitrogen 1.4-3.2 $\mathrm{mg} \mathrm{L}^{-1}$, orthophosphate 3.3-4.3 $\mathrm{mg} \mathrm{P} \mathrm{L}^{-1}$ ), of very high oxygen demand (chemical oxygen demand 12,559-14,254 $\mathrm{mg} \mathrm{L}^{-1}$, tannin and lignin 3066-5150 $\mathrm{mg} \mathrm{L}^{-1}$ as tannic acid, volatile fatty acids $\left.1564-2132 \mathrm{mg} \mathrm{L}^{-1}\right)$, and very toxic to aquatic life $(96-\mathrm{h}$ median lethal concentration of $0.74 \%$ leachate). The leachate at 1.5 years old in the closure period had lower oxygen demand and higher ammonia, and became less acidic and darker. The leachate had a 5-day biochemical oxygen demand to chemical oxygen demand ratio of 0.33 in the placement period and 0.14 in the late closure period. Volatile fatty acids accounted for 6 to $34 \%$ chemical oxygen demand, varying as the pile developed and with woodwaste age. Tannin and lignin accounted for 33 to $45 \%$ chemical oxygen demand. More than $98 \%$ contaminants were in dissolved form. The monthly variation of leachate quality was likely a result of both temperature and precipitation. $\mathrm{pH}$ was significantly correlated to chemical oxygen demand, tannin and lignin, and volatile fatty acids.
\end{abstract}

Key words: woodwaste, leachate, chemical oxygen demand, tannin, lignin, volatile fatty acids

\section{Introduction}

Leachate is generated when water percolates through a large mass of solid material as contaminated liquid. Wood leachate may be generated when rainfall, runoff or sprinkling water percolates through woodpiles, log yards, wood product storage areas, and woodwaste disposal sites of various wood processing mills and barge loading facilities. Naturally occurring wood constituents, preservatives, metals from the facilities, and wood decomposition by-products may be present in wood leachate. Wood leachate extracted by water in laboratory study (Field et al. 1988; Peters et al. 1976; Taylor et al. 1996; Temmink et al. 1989) or leached in open fields (Bailey et al. 1999; Hunter et al. 1993; Peters et al. 1976; Taylor and Carmichael 2003; Woodhouse and Duff 2004; Zenaitis et al. 2002) has been characterized as acidic, of very high oxygen demand, and toxic to aquatic organisms. The reported chemical composition of wood leachate varies with wood type, wood component (bark, heartwood, sapwood or foliage), waste compaction, leaching time and characteristics of leaching water.

In regions such as British Columbia, Canada, where forestry is one of the major industrial sectors, collection and disposal of woodwaste is an immense task. Wood-

\footnotetext{
*Corresponding author; wdtao@yahoo.com
}

waste, especially when it is not covered, poses a serious threat to surface and ground water due to leachate generation. Leachate flow rate and contaminant concentrations vary significantly over time as the landfill develops, through closure and after closure (Farquhar 1989; Forgie 1988). Operation flexibility should be considered in treatment plant design with regard to the time-variable nature of the leachate from woodwaste piles. The types, amounts and production rates of contaminants appearing in the leachate at a landfill are influenced by several factors that are difficult to quantify reliably in a landfill (El-Fadel et al. 1997; Farquhar 1989). It is, therefore, necessary to rely on data and experience from other landfill investigations. However, long-term monitoring and characterization of woodwaste leachate have not been reported to date.

Refuse age and corresponding landfill decomposition stage are usually the major determinants of leachate composition (El-Fadel et al. 1997). The present study monitored the leachate induced by precipitation on a cedar woodwaste pile for six consecutive years, including both the placement and closure periods. Based on continual and occasional monitoring data of leachate quality, this study assessed the physical-chemical properties and toxicity of the woodwaste leachate. Temporal variations in leachate quality were examined with regard to the development sequence of the woodwaste pile and local weather conditions. Further, it discussed the impli- 
cations of leachate characteristics to treatment of woodwaste leachate.

\section{Materials and Methods}

\section{Woodwaste Pile and Leachate Pool}

The woodwaste pile of concern was a large open storage of sawdust, shredded bark and roots, off-specification wood chips and process trimmings. It was located adjacent to the Fraser River in Mission, British Columbia, Canada. Several wood processing facilities, mostly cedar shake and shingle mills, stacked their cedar woodwaste together in an effort to gain a sufficient quantity for either selling it as fuel to electrical cogeneration facilities or using it as a raw material for some other industrial processes (e.g., charcoal production). Since 1992, this pile had been receiving new woodwaste and growing up from an area of approximately 150 to $200 \mathrm{~m}$ in diameter and to $20 \mathrm{~m}$ high in 1999, adjoining the working site of a wood chips company at a higher elevation. There was not any intentional compaction, placement sequence, bottom lining or cover while placing the waste. The stored woodwaste was delivered to a pulp mill as a fuel supplement to its cogeneration boiler on an as-requested basis in 1999 and 2000. Consequently, the pile was reduced to about $12 \mathrm{~m}$ high in 2000 . The pile size increased again to $20 \mathrm{~m}$ high in early 2001 . In summer 2001 , the $8-\mathrm{m}$ high pile cap was removed to become a working site, and new piles formed in the adjacent area. In general, the pile of concern underwent a placement period before summer 2001, followed by closure.

This area is characterized by a coastal climate with colder, wet winters and warm, drier summers. The climate information during the study period at the nearby "Abbotsford A" meteorological station (elevation of $57.9 \mathrm{~m}$ ) indicated that the mean monthly temperature ranged from $20.3^{\circ} \mathrm{C}$ in July 2004 to $2.9^{\circ} \mathrm{C}$ in January 2004 (Fig. 1). The annual precipitation was 1255 to $1797 \mathrm{~mm}$ between 1999 and 2004, with 22.5 to $44.4 \%$ occurring during the spring-summer period (April-September).

When precipitation fell directly on the pile and percolated through the woodwaste, it produced an amber leachate. A pool of leachate, approximately $20 \mathrm{~m}$ by 70 $\mathrm{m}$, had formed in a natural depression on one side of the woodwaste pile since its establishment. A very strong pungent, woody smell emanated from the leachate pool. In the dry summers from July to September, the pool was shallow, but it could collect one metre of leachate through the wetter months.

The quantity of leachate generated is site-specific. It depends on weather conditions, landfill cover and lining, and moisture content and field capacity of the solid waste. No runoff was observed on this woodwaste pile. Based on the annual precipitation and evaporation norms between 1971 and 2000 of nearby meteorological stations (Environment Canada 2004), an annual leachate generation of $24,680 \mathrm{~m}^{3}$ was estimated with a simplified water balance model (El-Fadel et al. 1997; Farquhar 1989). Directly underlying the pile was an impermeable stratum consisting of silt and clay, ranging from 0.9 to $4.1 \mathrm{~m}$ thick. Beneath this stratum was an aquifer. The leachate pool could only hold about $1000 \mathrm{~m}^{3}$ of leachate, while the majority might flow to the other sides of the pile or penetrate weak spots of the impermeable stratum beneath the pile.

\section{Field Measurement and Laboratory Analysis}

The woodwaste leachate was collected from the leachate pool in 1-L plastic bottles at weekly intervals mostly during the warmer months (March to October) between 1999 and 2004. The leachate was analyzed to facilitate other studies and not conducted on a consistent frequency. Chemical oxygen demand (COD), tannin and lignin (T\&L), volatile fatty acids (VFAs), ammonia, nitrate, nitrite, orthophosphate and $\mathrm{pH}$ of the woodwaste leachate were measured continually through the placement and closure periods of the woodwaste pile. Suspended solids and 5-day biochemical oxygen demand $\left(\mathrm{BOD}_{5}\right)$ were measured in 1999 and 2000 and checked occasionally in the closure period. In 1999, 96-h median lethal concentration to rainbow trout was determined. Total Kjeldahl nitrogen (TKN) and total phosphorus (TP) were analyzed twice and three times, respectively. Some other parameters (organic carbon, colour, etc.) were only analyzed a few times (Frankowski 2000; Masbough 2002) and are not presented here.

Field measurements were made while sampling. Water temperature and dissolved oxygen were measured in the leachate pool from 1999 to 2002, using a portable YSI Model 54 DO meter (Yellow Springs Instrument, Yellow Springs, Ohio). Redox potential (Eh) was determined from millivolt readings from 2002 to 2004, using

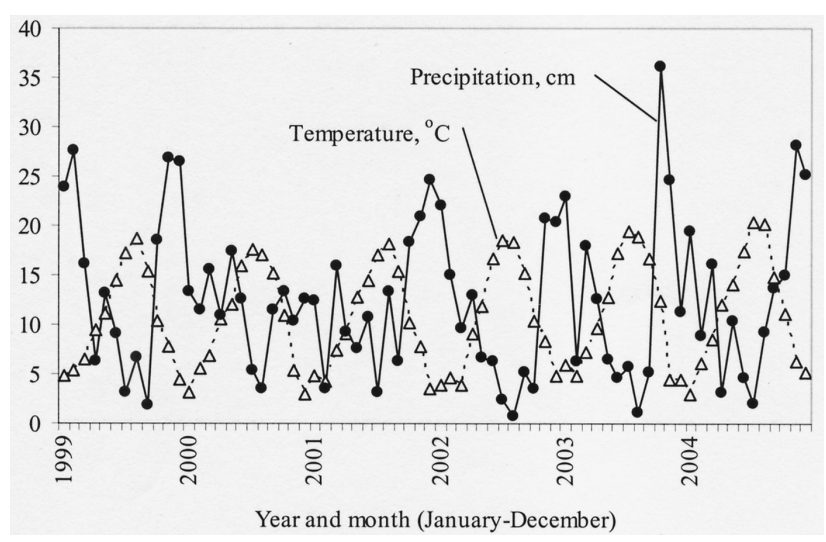

Fig. 1. Variation of monthly air temperature and precipitation at "Abbotsford A" meteorological station. Data from Environment Canada (2004). 
a Horiba D-13 US model pH meter (Horiba, Ltd., Kyoto, Japan) equipped with a $\mathrm{Pt}-\mathrm{Ag} / \mathrm{AgCl}$ combination electrode (Broadley James Corporation, Irvine, Calif.).

Standard methods (APHA et al. 1999) were followed for analysis of $\mathrm{pH}\left(4500-\mathrm{H}^{+}\right.$electrometric $)$with the Horiba pH meter, solids (2540), COD (5220D closed reflux, colorimetric) with a Hach DR/2000 spectrophotometer (Hach Co., Loveland, Colo.), T\&L (5550B Folin phenol colorimetric) with the Hach spectrophotometer, BOD (5210B 5-day incubation; seeded with sediment of the leachate pool), ammonia (4500$\mathrm{NH}_{3} \mathrm{H}$ flow injection), nitrate plus nitrite $\left(4500-\mathrm{NO}_{3}{ }^{-} \mathrm{I}\right.$ cadmium reduction flow injection), TKN (4500-Norg D block digestion and flow injection), TP (4500-P H manual digestion and flow injection) and orthophosphate (4500-P G flow injection). Flow injection analyses were done on a Lachat Quick-Chem 8000 automatic flowinjection ion analyzer (Lachat Instruments, Milwaukee, Wis.) with absorbance detectors. T\&L were analyzed with tannic acid as standards and given as tannic acid. The analyses of COD and T\&L were not affected by the colour of water samples because the samples were diluted 25 and 250 to 1000 times, respectively, with ultra-pure water to bring them within method ranges, 20 to $900 \mathrm{mg} \mathrm{L}^{-1} \mathrm{COD}$ and $\leq 8 \mathrm{mg} \mathrm{L}^{-1} \mathrm{~T} \& \mathrm{~L}$.

VFAs were analyzed by gas chromatography (HPGC 5880A; Supelco, Inc. GC Bulletin 751G). The GC detected acetic acid $\left(\mathrm{CH}_{3} \mathrm{COOH}\right)$, propionic acid $\left(\mathrm{C}_{2} \mathrm{H}_{5} \mathrm{COOH}\right)$, iso-butyric acid and butyric acid $\left(\mathrm{C}_{3} \mathrm{H}_{7} \mathrm{COOH}\right)$, valeric acid $\left(\mathrm{C}_{4} \mathrm{H}_{9} \mathrm{COOH}\right)$ and hexanoic acid $\left(\mathrm{C}_{5} \mathrm{H}_{11} \mathrm{COOH}\right)$. Acute toxicity tests using rainbow trout followed the procedure described by Environment Canada (1990), with sufficient oxygen and $\mathrm{pH}$ adjusted to 4.5 to 5.0 .

\section{Statistical Analysis}

The monthly averages of leachate quality parameters were used for statistical analysis instead of values of individual samples because the leachate was collected at variable frequencies across months. The number of months monitored is represented by $n$. The correlation of leachate quality to air temperature and precipitation was analyzed by multiple linear regressions, which output the coefficient of determination, $R^{2}$. Temporal variation of the ratio of VFAs theoretical oxygen demand (ThOD) to COD and correlation between quality parameters were checked by Spearman's rank correlation analysis. A correlation was considered significant at a probability value of $P \leq 0.05$.

\section{Results}

\section{Physical and Toxicological Properties}

The leachate pool acted as a settling pond, with the majority of solids and organic matter present in a dis- solved form (through microfiber glass filters with pore size of $0.7 \mu \mathrm{m}$ ). The woodwaste leachate had $<0.5 \mathrm{mg} \mathrm{L}^{-1}$ settleable solids, and 19 to $43 \mathrm{mg} \mathrm{L}^{-1}$ total suspended solids. Over $99 \%$ of the solids present in the leachate were dissolved. More than 98\% COD was soluble.

The woodwaste leachate exhibited an amber colour at about $\mathrm{pH} 4$, and became darker with increasing $\mathrm{pH}$, suggesting that it was largely due to some forms of coloured weak acids, similar to tannic acid, that undergo a shift in their protonation as $\mathrm{pH}$ changes and subsequently their spectral properties. Anion exchange resin Duolite S37 columns $(10 \mathrm{~cm}$ long $\times 2)$ completely removed the visual colour of woodwaste leachate. Less than $5 \% \mathrm{~T} \& \mathrm{~L}$ was found left in the column filtrate.

Leachate temperature (Table 1) was higher than air temperature (Fig. 1), with an average difference of $7.1^{\circ} \mathrm{C}$ between 1999 and 2002. The higher leachate temperature could result from absorption of solar energy by the dark woodwaste leachate in the leachate pool and from anaerobic decomposition in the woodwaste pile.

The woodwaste leachate exerted acute toxicity to rainbow trout at a 96-h median lethal concentration of $0.74 \%(\mathrm{v} / \mathrm{v})$ full-strength leachate in 1999 . The toxicity may be attributed to tannins, lignins, zinc and low $\mathrm{pH}$, but is not confirmed yet.

\section{Change over Age of Woodwaste Pile}

Figure 2 shows variation of the woodwaste leachate quality at monthly intervals for six years. The yearly averages and deviations are presented in Table 1 . There was not an obvious change in leachate quality in the placement period from 1999 to 2001. The "young" leachate in the placement period contained very high concentrations of COD, T\&L and VFAs. The concentrations of COD and VFAs were similar to the young leachate of municipal solid waste landfills (El-Fadel et al. 1997; Farquhar 1989). The concentrations of COD, T\&L and VFAs began to decrease in approximately 1 , 1.5 and 1.5 years, respectively, after stopping placement of new woodwaste in the summer of 2001. There was a rapid decrease in the concentrations of COD, T\&L and VFAs in 2004, 2.5 years into the closure period. COD concentration of the old woodwaste leachate decreased to values similar to that of municipal landfill leachate at a refuse age of 10 to 20 years (Farquhar 1989). $\mathrm{pH}$ varied between 3.3 and 3.9 from 1999 to 2002, and began to increase starting from 2003. Because of the very high oxygen demand, dissolved oxygen was always below 0.6 $\mathrm{mg} \mathrm{L}^{-1}$. Redox potential did not show a clear trend of variation from 2002 to 2004 .

\section{Composition of Oxygen Demand}

The young woodwaste leachate had a $\mathrm{BOD}_{5}: \mathrm{COD}$ ratio of 0.33 on average from June through December 1999, and 
TABLE 1. Variation of woodwaste leachate quality over years ${ }^{\mathrm{a}}$

\begin{tabular}{|c|c|c|c|c|c|c|}
\hline $\begin{array}{l}\text { Sampling year } \\
\text { Monitoring period } \\
\text { (number of months) }\end{array}$ & $\begin{array}{c}1999 \\
\text { May-Dec. } \\
(n=3-5)\end{array}$ & $\begin{array}{c}2000 \\
\text { May-Sep. } \\
(n=3-5)\end{array}$ & $\begin{array}{c}2001 \\
\text { Jun.-Oct. } \\
(n=4-5)\end{array}$ & $\begin{array}{c}2002 \\
\text { Jun.-Nov. } \\
(n=3-5)\end{array}$ & $\begin{array}{c}2003 \\
\text { Feb.-Oct. } \\
(n=4-5)\end{array}$ & $\begin{array}{c}2004 \\
\text { Mar.-Oct. } \\
(n=7-8)\end{array}$ \\
\hline Temperature, ${ }^{\circ} \mathrm{C}$ & $12.6 \pm 1.8$ & $28.9 \pm 2.2$ & $19.7 \pm 4.1$ & $22.3 \pm 1.2$ & $\mathrm{ND}^{\mathrm{b}}$ & ND \\
\hline $\begin{array}{l}\text { Dissolved oxygen, } \\
\mathrm{mg} \mathrm{L}^{-1}\end{array}$ & $0.3 \pm 0.1$ & $0.2 \pm 0.1$ & $0.4 \pm 0.1$ & $0.5 \pm 0.1$ & ND & ND \\
\hline Redox potential, $\mathrm{mV}$ & ND & ND & ND & $258 \pm 8$ & $329 \pm 48$ & $219 \pm 41$ \\
\hline $\mathrm{pH}$ & $3.6 \pm 0.1$ & $3.4 \pm 0.0$ & $3.7 \pm 0.1$ & $3.7 \pm 0.1$ & $4.3 \pm 0.3$ & $5.8 \pm 0.7$ \\
\hline $\begin{array}{l}\text { Volatile fatty acids, } \\
\mathrm{C}_{2}-\mathrm{C}_{6}, \mathrm{mg} \mathrm{L}^{-1}\end{array}$ & $1564 \pm 463$ & $2132 \pm 303$ & $2063 \pm 60$ & $2211 \pm 426$ & $994 \pm 326$ & $191 \pm 221$ \\
\hline $\begin{array}{l}\text { Chemical oxygen } \\
\text { demand, } \mathrm{mg} \mathrm{L}^{-1}\end{array}$ & $12,626 \pm 4369$ & $14,254 \pm 3049$ & $12,559 \pm 1295$ & $10,214 \pm 1073$ & $6068 \pm 1446$ & $3908 \pm 1634$ \\
\hline $\begin{array}{l}\text { Tannin and lignin, } \\
\mathrm{mg} \mathrm{L}^{-1} \text { as tannic acid }\end{array}$ & $3066 \pm 622$ & $5150 \pm 1210$ & $3580 \pm 437$ & $3372 \pm 228$ & $1839 \pm 491$ & $1100 \pm 271$ \\
\hline Ammonia, $\mathrm{mg} \mathrm{N} \mathrm{L}^{-1}$ & $1.1 \pm 0.9$ & $3.1 \pm 0.9$ & $1.8 \pm 1.0$ & $1.8 \pm 0.9$ & $3.2 \pm 4.3$ & $11.3 \pm 10.5$ \\
\hline $\begin{array}{l}\text { Nitrate and nitrite, } \\
\text { mg N L-1 }\end{array}$ & $0.27 \pm 0.33$ & $0.15 \pm 0.10$ & $0.14 \pm 0.12$ & $0.08 \pm 0.05$ & $0.50 \pm 0.14$ & $0.26 \pm 0.15$ \\
\hline $\begin{array}{l}\text { Orthophosphate, } \\
\text { mg P L-1 }\end{array}$ & $3.5 \pm 0.9$ & $4.3 \pm 1.0$ & $3.3 \pm 0.2$ & $2.1 \pm 0.5$ & $1.5 \pm 1.1$ & $2.9 \pm 1.8$ \\
\hline
\end{tabular}

${ }^{a}$ Mean \pm standard error of monthly average monitoring data.

${ }^{b} \mathrm{ND}$; No data.

older leachate had a $\mathrm{BOD}_{5}: \mathrm{COD}$ ratio of 0.14 on average in July and August 2004. Tannins and lignins are noted for their resistance to biodegradation. On an annual basis, the ratio of T\&L ThOD:COD varied between 0.33 and 0.45 . VFAs are easily biodegradable carbon sources. The ratio of annual VFAs ThOD:COD apparently increased $\left(r_{s}=0.78\right.$, $P<0.01$ ) from 0.16 in 1999 to 0.34 in 2002, and then significantly decreased $\left(r_{s}=-0.93, P<0.001\right)$ to 0.25 in 2003 and 0.06 in 2004 (Fig. 3). T\&L and VFAs together accounted for 43 to $73 \%$ of COD on an annual basis.

The proportions of lower molecular weight VFAs (acetic and propionic) decreased gradually from 1999 to 2002 and then increased (Fig. 4). In general, acetic acid accounted for 36 to $45 \%$ of the total VFAs.

The concentrations of COD, T\&L and VFAs were significantly, negatively correlated to $\mathrm{pH}$ (Fig. 5), imply-

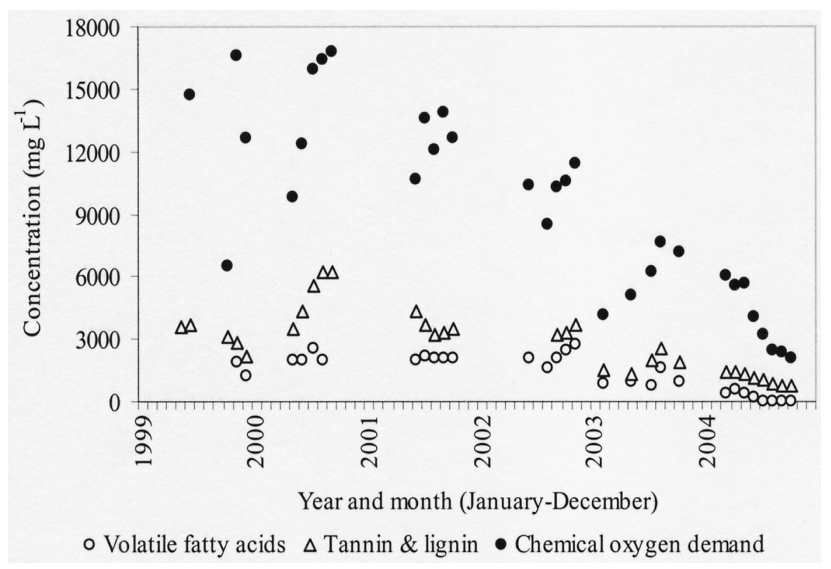

Fig. 2. Temporal variation of woodwaste leachate quality. ing that COD was largely influenced by organic acids, such as VFAs and the tannic acid-like complex.

\section{Nutrient Levels}

Ammonia, nitrate, nitrite and orthophosphate concentrations in the woodwaste leachate were very low either relative to the concentrations of COD, T\&L and VFAs (Table 1) or in comparison to the nitrogen and phosphorus concentrations in municipal landfill leachate (El-Fadel et al. 1997; Farquhar 1989), although there was a sharp increase in ammonia nitrogen in late 2004 (Fig. 2). The concentration of TP in woodwaste leachate was $4.0 \mathrm{mg} \mathrm{L}^{-1}$ in 1999 and $6.6 \mathrm{mg} \mathrm{L}^{-1}$ in 2004. The concentration of TKN in woodwaste leachate was $47.3 \mathrm{mg} \mathrm{L}^{-1}$ in 2004. The concentrations of TKN and TP

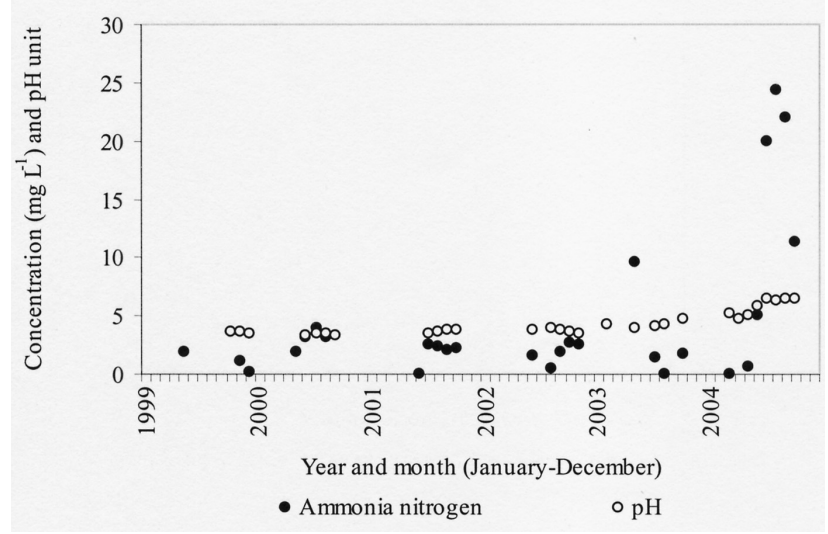




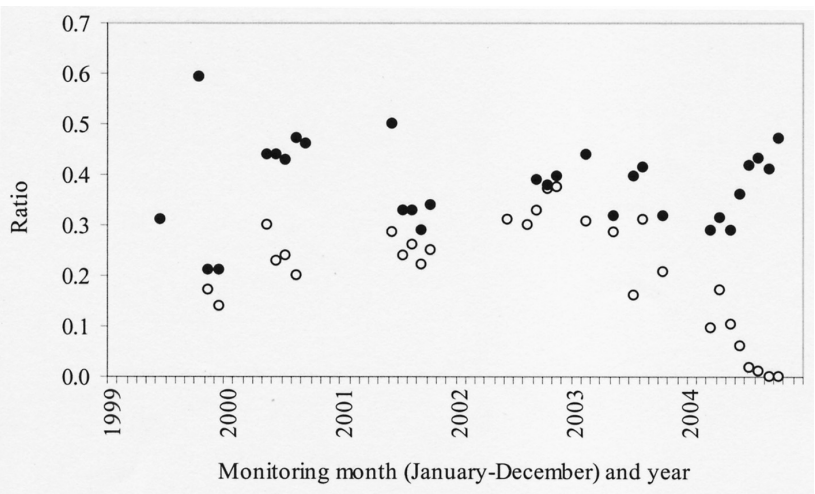

- Theoretical oxygen demand of volatile fatty acids to chemical oxygen demand - Theoretical oxygen demand of tannin \& lignin to chemical oxygen demand

Fig. 3. Temporal variation in composition of chemical oxygen demand of woodwaste leachate.

in woodwaste leachate fell into the category of leachate from $>20$-year-old landfill refuse (Farquhar 1989).

\section{Seasonal Variation}

The number of months monitored each year was inadequate to show a complete seasonal variation in woodwaste leachate quality. The monthly air temperature and precipitation were not correlated with monthly average concentrations of COD $\left(R^{2}=0.03, P=0.76\right)$ and VFAs $\left(R^{2}=0.07, P=0.63\right)$, while T\&L concentration was significantly correlated to temperature and precipitation $\left(R^{2}=0.37, P=0.03\right)$ during 1999 to 2002 . The correlations of COD, T\&L and VFAs concentrations to temperature and precipitation were not improved by replacing precipitation with the cumulative precipitation of the most recent two months.

\section{Discussion}

\section{Characteristics of Woodwaste Leachate}

It can take several months for the leachate to arrive at the base of the landfill, depending on the refuse type, compaction and depth (Farquhar 1989). A significant correlation of T\&L concentration with air temperature and precipitation suggested immediate generation of leachate from the woodwaste pile, probably because of lack of covers, litthe compaction and low field capacity of the woodwaste.

In general, the "young" woodwaste leachate produced in the pile's placement period was amber, acidic, nutrient-poor, of very high oxygen demand, and very toxic to aquatic life; the "older" leachate in the late closure period had lower oxygen demand and higher ammonia, and became less acidic and darker. This uncovered woodwaste pile contained sawdust and shredded bark and roots, providing greater exposure than woodpile and

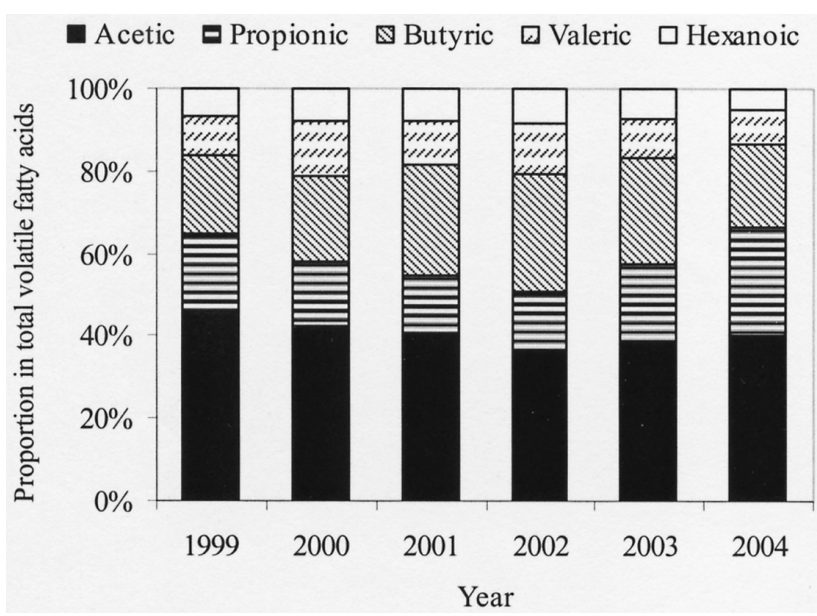

Fig. 4. Yearly variation of the proportions of individual acids in the total volatile fatty acids of woodwaste leachate.

compacted woodwaste to physical, chemical and biochemical reactions. The leachate from this woodwaste pile, except in the late closure period, therefore, had lower $\mathrm{pH}$ and much higher oxygen demand in terms of $\mathrm{COD}, \mathrm{T} \& \mathrm{~L}$ or $\mathrm{BOD}_{5}$ than the leachate from a 2-year-old cedar waste landfill (Peters et al. 1976), leachate from highway entrances and off-ramps filled with woodwaste (Hunter et al. 1993), leachate from woodpiles (Taylor and Carmichael 2003), bark wastewater (Field et al. 1988), stormwater runoff from sawmills (Bailey et al. 1999) and log yard runoff (Woodhouse and Duff 2004; Zenaitis et al. 2002).

The organic carbon of woodwaste leachate was a mixture of lignins, tannins, fatty acids and other unknown dissolved organic compounds. Characterization of wood extractives (Gabrielii et al. 2000; Sun et al. 2001) suggests that hemicellulose is probably among the unknown organic carbon components of wood leachate. The significant correlation of COD, T\&L and VFAs to $\mathrm{pH}$ suggested that the woodwaste leachate contained

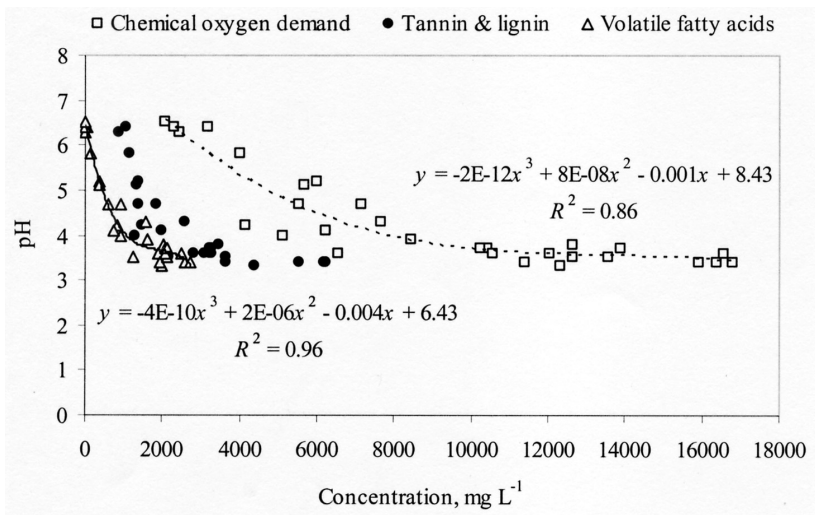

Fig. 5. Correlation of $\mathrm{pH}$ to monthly concentrations of oxygen-demanding substances of woodwaste leachate. 
such organic acids as humic and fulvic acids that are similar to tannic acid, in addition to VFAs.

The young woodwaste leachate had a smaller $\mathrm{BOD}_{5}: \mathrm{COD}$ ratio $(0.33)$ and larger T\&L ThOD:COD ratio $(0.33-0.45)$, indicating resistance to biodegradation. The woodwaste leachate had a $\mathrm{BOD}_{5}: \mathrm{COD}$ ratio similar to, and a T\&L ThOD:COD ratio higher than, log yard runoff (Woodhouse and Duff 2004; Zenaitis et al. 2002). The contribution of easily biodegradable VFAs to COD in the late closure period decreased rapidly over time, resulting in a more recalcitrant leachate. VFAs declined faster than T\&L, and COD declined in the closure period, suggesting that microbial decomposition within the woodwaste pile reduced the availability of labile organic compounds for percolation.

Acetic acid, the main component of VFAs in woodwaste leachate, is a catabolic product of anaerobic fermentation. Other VFAs with even numbers of carbon atoms are formed from acetic acid through condensation reactions; the VFAs with odd numbers of carbon atoms are formed through various combinations of microorganism-induced cleavage and condensation reactions (Forgie 1988).

The woodwaste leachate colour responded to the change of $\mathrm{pH}$ that was significantly correlated to concentrations of COD, T\&L and VFAs. VFAs $\mathrm{C}_{2}-\mathrm{C}_{6}$ species are colourless except that hexanoic acid may be slightly yellow. T\&L and humic substances are highly coloured compounds that appear to be the major source of woodwaste leachate colour.

The toxicity of wood leachate is mostly attributed to phenolic compounds (including tannins), lignins, tropolones, terpenes, zinc, lignans, low $\mathrm{pH}$ and other unidentified constituents (Bailey et al. 1999; Borga et al. 1996; Field et al. 1988; Peters et al. 1976; Taylor et al. 1996; Taylor and Carmichael 2003; Temmink et al. 1989). With reference to the toxicity bioassays by these previous studies, T\&L and low $\mathrm{pH}$ were most likely responsible for the toxicity of the woodwaste leachate.

\section{Temporal Variation of Chemical Properties}

The temporal variation of woodwaste leachate quality (Fig. 2) showed a pattern similar to, but shorter than, that of municipal landfill leachate (Farquhar 1989). It may reach peak concentrations in the earlier months of leaching (Farquhar 1989). In the placement period, the leachate came from both fresh and leached woodwaste, and its strength varied at high concentrations, likely with the weather conditions and the amount of new waste placed. The woodwaste pile in this study had no cover and the waste was placed without compaction, undergoing a faster leaching process in comparison to aspen woodpiles (Taylor and Carmichael 2003) and municipal landfills (Farquhar 1989). Obvious decreases in the eas- ily biodegradable VFAs and recalcitrant T\&L occurred 1.5 years after placement of new woodwaste stopped.

Microbial decomposition contributes to the characteristics of landfill leachate (Farquhar 1989; Forgie 1988). When fresh woodwaste was continually piled up, hydrolysis and fermentation solubilized waste components and produced organic acids and alcohols. As rainfall percolated through the waste, contaminants were mobilized into the liquid phase through dissociation and suspension from the stationary phase, thus producing a concentrated leachate. As the low dissolved oxygen and redox potential of the woodwaste leachate in the leachate pool suggested, anaerobic decomposition might have predominated the degradation process in the woodwaste pile in the closure period. Anaerobic reactions decomposed the biodegradable organic matter to methane, $\mathrm{CO}_{2}$ and metabolic intermediates, and left higher molecular weight organics, including lignins and tannins. With development of anaerobic decomposition, the ratios of $\mathrm{BOD}_{5}$ to COD and VFAs ThOD to COD decreased. The anaerobic reducing environment within the woodwaste pile caused an increase in the concentration of ammonia.

With reference to the leachate temperature, the woodwaste pile was likely far from optimum for the anaerobic processes (Metcalf and Eddy 2003). Higher temperature in the summers (Fig. 1) would improve microbial metabolism in the woodwaste pile to produce concentrated leachate. In the wet winters, frequent rainfall (Fig. 1) would raise moisture content of the woodwaste and likely enhance microbial activity and leaching of soluble compounds. T\&L is more resistant to biodegradation than VFAs and the aggregate parameter COD. The concentration of T\&L in the leachate pool should be close to the fresh woodwaste leachate. The significant correlation of T\&L concentration to air temperature and precipitation confirmed the effect of natural factors on the woodwaste leachate quality. Taylor and Carmichael (2003) reported a significant BOD decline due to 10 to 12 days of storing wood leachate in a catch basin under anoxic conditions. VFAs and COD in the leachate pool were probably reduced by biodegradation during the warm summer period compared to the colder winter period. Subsequently, correlations of VFAs and COD to air temperature and precipitation diminished. The seasonal variation in monitoring results was a mixed effect of precipitation and air temperature on the generation of woodwaste leachate in the woodwaste pile as well as dilution or concentration and degradation in the leachate pool. Consequently, no simple pattern of seasonal variation was identified in leachate quality.

\section{Implications to Selection of Treatment Processes}

Treatment options for leachate include aerobic and anaerobic biological processes, and various types of physical- 
chemical treatment processes (Forgie 1988). Field et al. (1988) found that anaerobic digestion helped degrade soluble COD from bark. Log yard runoff has been effectively treated by a bench-scale aerobic batch bioreactor (Zenaitis et al. 2002), a laboratory-scale aerobic trickling filter (Woodhouse and Duff 2004) and ozonation (Zenaitis and Duff 2002). Frankowski (2000), Hunter et al. (1993) and Masbough (2002) have proved the applicability of constructed wetlands for treatment of woodwaste leachate.

Very low concentrations of suspended solids suggest that sedimentation and flocculation are not practical options for treatment of woodwaste leachate. High concentrations of natural polymers, such as tannins and lignins, imply the removal potential by adsorption. High concentrations of VFAs in the woodwaste leachate could be efficiently removed by biological processes.

In the cases Forgie (1988) reviewed for leachate treatment, aerobic biological systems operated better with a $\mathrm{BOD}_{5}: \mathrm{N}: \mathrm{P}$ ratio of about 100:5:1. The "young" woodwaste leachate had a $\mathrm{BOD}_{5}$ :(inorganic N):(orthophosphate $\mathrm{P}$ ) ratio of 1195:0.4:1 on average in 1999, suggesting the need for nutrient supplementation for aerobic treatment of woodwaste leachate.

Biological treatment processes rely on the establishment and activity of a mixture of microorganisms, which may be inhibited by toxic components of the waste stream. Inhibition on bacterial metabolism by aspen leachate has been found at wood leachate concentrations below $0.3 \%$ (Taylor et al. 1996). Median effective inhibition concentrations derived from bacterial luminescence assays were $<10 \%$ of full-strength aspen wood leachate and more often approached $1 \%$ (Taylor and Carmichael 2003), and 1.9 to $91 \%(\mathrm{v} / \mathrm{v}$ ) of $\log$ yard runoff (Woodhouse and Duff 2004; Zenaitis et al. 2002). The $50 \%$ inhibitory concentration of bark tannins to methanogens averaged approximately $600 \mathrm{mg} \mathrm{L}^{-1}$ COD or $350 \mathrm{mg} \mathrm{L}^{-1}$ tannin solids (Field et al. 1988). Low $\mathrm{pH}$ and high concentration of T\&L are probably the major inhibitory factors for biological treatment of woodwaste leachate.

Conventional biological leachate treatment is most appropriate when the $\mathrm{BOD}_{5}: \mathrm{COD}$ ratio is high $(>0.4)$ and the molecular weight of the majority of the organics is less than 500 (Forgie 1988). The woodwaste leachate had a lower $\mathrm{BOD}_{5}: \mathrm{COD}$ ratio $(0.14-0.33)$, and $\mathrm{T} \& \mathrm{~L}$ that accounted for 33 to $47 \%$ of COD has a molecular weight probably higher than or similar to 1701 for tannic acid. With regard to low $\mathrm{pH}$, low $\mathrm{BOD}_{5}$ :COD ratio, high $\mathrm{BOD}_{5}: \mathrm{N}: \mathrm{P}$ ratio and potential toxicity to microorganisms, anaerobic treatment systems with a long hydraulic retention time, such as constructed wetlands (Hunter et al. 1993; Tao and Hall 2004), are preferred for treatment of woodwaste leachate.

\section{Conclusions}

A woodwaste pile without cover and compaction generated a leachate with quality changing faster over years than that of municipal landfills. The mixed effect of air temperature and precipitation resulted in a woodwaste leachate quality without a simple pattern of seasonal change. Overall, the woodwaste leachate was highly coloured, acidic, of very high oxygen demand, nutrientpoor and very toxic to aquatic life. The concentrations of COD, T\&L and VFAs changed over years as the woodwaste pile developed, especially after closure. The treatment processes should consider flexibility in influent quality with regard to the yearly variable nature of woodwaste leachate.

The ratio of VFAs ThOD:COD increased as the woodwaste pile developed, and decreased as it stopped receiving new waste. T\&L accounted for more than onethird $(33-45 \%)$ of COD on an annual basis. The organic compounds that formed 27 to $57 \%$ COD are still not known. The leachate characters of recalcitrance, lack of nutrients and possible inhibition on microbial activity suggest a preference for constructed wetlands to treat woodwaste leachate at a long hydraulic retention time.

\section{Acknowledgements}

This research was supported by an NSERC grant to K. Hall and Network of Centres of Excellence - Sustainable Forest Management funding to S. Duff. Some laboratory analyses by Paula Parkinson and the technical assistance of Susan Harper in the UBC Environmental Engineering Laboratory are greatly appreciated.

\section{References}

American Public Health Association (APHA), American Water Works Association, Water Environment Federation. 1999. Standard methods for the examination of water and wastewater, $20^{\text {th }}$ edition.

Bailey HC, Elphick JR, Potter A, Chao E, Konasewich D, Zak JB. 1999. Causes of toxicity in stormwater runoff from sawmills. Environ. Toxicol. Chem. 18:1485-1491.

Borga P, Elowson T, Liukko K. 1996. Environmental loads from water-sprinkled softwood timber: 2 . Influence of tree species and water characteristics on wastewater discharges. Environ. Toxicol. Chem. 15:1445-1454.

El-Fadel M, Findikakis AN, Leckie JO. 1997. Modeling leachate generation and transport in solid waste landfills. Environ. Technol. 18:669-686.

Environment Canada. 1990. Biological test method: acute lethality test using rainbow trout. Environmental Protection Series EPA1/RM/9, Ottawa, Ont. 
Environment Canada. 2004. National Climate Data and Information Archive. Available on-line at: http://www. climate.weatheroffice.ec.gc.ca/Welcome_e.html. [Reviewed: January 27, 2004; accessed: March 6, 2005].

Farquhar GJ. 1989. Leachate: production and characterization. Can. J. Civ. Eng. 16:317-325.

Field JA, Leyendeckers MJH, Alvarez RS, Lettinga G, Habets LHA. 1988. The methanogenic toxicity of bark tannins and the anaerobic biodegradability of water soluble bark matter. Water Sci. Technol. 20:219-240.

Forgie DJL. 1988. Selection of the most appropriate leachate treatment methods Part 1: a review of potential biological leachate treatment methods. Water Poll. Res. J. Canada 23:308-328.

Frankowski KA. 2000. The treatment of wood leachate using constructed wetlands. M.A.Sc. thesis, University of British Columbia, Vancouver, British Columbia.

Gabrielii I, Gatenholm P, Glasser WG, Jain RK, Kenne L. 2000. Separation, characterization and hydrogelformation of hemicellulose from aspen wood. Carbohydrate Polymers 43:367-374.

Hunter R, Birkbeck AE, Coombs G. 1993. Innovative marsh treatment systems for control of leachate and fish hatchery wastewaters, p. 477-484. In Moshiri GA (ed.), Constructed wetlands for water quality improvements. Lewis Publishers, Baca Raton, Fla.

Masbough A. 2002. The effectiveness of constructed wetlands for treatment of wood leachate. M.A.Sc. thesis, University of British Columbia, Vancouver, British Columbia.

Metcalf and Eddy. 2003. Wastewater engineering - treatment and reuse, $4^{\text {th }}$ edition, p. 984-987. McGraw-Hill, New York.
Peters GB, Dawson HJ, Hrutfiord BF, Whitney RR. 1976. Aqueous leachate from western red cedar: effects on some aquatic organisms. J. Fish. Res. Board Canada 33:2703-2709.

Sun RC, Fang JM, Tomkinson J, Geng ZC, Liu JC. 2001. Fractional isolation, physico-chemical characterization and homogeneous esterification of hemicelluloses from fast-growing poplar wood. Carbohydrate Polymers 44:29-39.

Tao W, Hall KJ. 2004. Dynamics and influencing factors of heterotrophic bacterial utilization of acetate in constructed wetlands treating woodwaste leachate. Water Res. 38:3442-3448.

Taylor BR, Carmichael NB. 2003. Toxicity and chemistry of aspen wood leachate to aquatic life: field study. Environ. Toxicol. Chem. 22:2048-2056.

Taylor BR, Goudey JS, Carmichael NB. 1996. Toxicity of aspen wood leachate to aquatic life: laboratory studies. Environ. Toxicol. Chem. 15:150-159.

Temmink JHM, Field JA, van Haastrecht JC, Merkelbach RCM. 1989. Acute and sub-acute toxicity of bark tannins in carp (Cyprinus carpio L.). Water Res. 23:341-344.

Woodhouse C, Duff SJB. 2004. Treatment of log yard runoff in an aerobic trickling filter. Water Qual. Res. J. Canada 39:232-238.

Zenaitis MG, Duff SJB. 2002. Ozone for removal of acute toxicity from logyard runoff. Ozone Sci. Eng. 24:83-90.

Zenaitis MG, Sandhu H, Duff SJB. 2002. Combined biological and ozone treatment of log yard runoff. Water Res. 36:2053-2061.

Received: January 4, 2005; accepted: July 8, 2005. 